\title{
Premature Thelarche and Precocious Puberty in a Three-Year-Old Girl with Granulosa Cell Tumor
}

\begin{tabular}{|c|c|}
\hline & ahra Ghanbari ${ }^{1 *}$ \\
\hline \multirow{5}{*}{$\begin{array}{l}\text { Article History: } \\
\text { Received April } 2013 \\
\text { Accepted May } 2013 \\
\text { Available online July } 2013\end{array}$} & \multirow{15}{*}{$\begin{array}{l}\text { Abstract } \\
\text { Granulosa cell tumors (GCTs) are tumors that arise from } \\
\text { granulosa cells, occurring in women } 50 \text { to } 55 \text { years of age but } \\
\text { may occur at any age whereas Juvenile granulosa cell tumors } \\
\text { usually occur in children and adolescents. A three years old girl } \\
\text { with breast development but without any significant past } \\
\text { medical history was referred to the Pediatric Clinic in Children } \\
\text { hospital(University of Medical Sciences, Tabriz, Iran) in July } \\
\text { 2011.We have reported this patient with premature thelarche } \\
\text { and isosexual precocity in this paper. Pelvic ultrasonography } \\
\text { showed a hypoechoic solid mass and abdominopelvic MRI } \\
\text { showed left adnexal mass with cystic components. Microscopic } \\
\text { features of the resected mass were characteristic of juvenile } \\
\text { GCT. Although in most of girls with precocious puberty the } \\
\text { etiology is idiopathic, some important causes, such as ovarian } \\
\text { tumors must be considered because most common presenting } \\
\text { manifestation of GCT in children is precocious puberty. }\end{array}$} \\
\hline & \\
\hline & \\
\hline & \\
\hline & \\
\hline Keywords: & \\
\hline Granulosa cell tumour & \\
\hline Juvenile granulosa cell tumour & \\
\hline Precocious puberty & \\
\hline Children & \\
\hline Corresponding Author & \\
\hline Zahra Ghanbari, & \\
\hline Physician, Islamic Azad University & \\
\hline Tabriz Branch, Iran & \\
\hline Tel: +989143057376 & \\
\hline
\end{tabular}

1-General Physician, Islamic Azad University Tabriz Branch, Iran

Int J Women's Health Reproduction Sci Vol. 1, No. 2, Summer 2013 


\section{Introduction:}

Granulosa cell tumors (GCTs) of ovary were initially described by Rokitansky in 1855(1). Granulosa cell tumors (granulosa-theca cell tumors) are tumors that arise from granulosa cell. These tumors are part of the sex cord-gonadal stromal tumor or nonepithelial group of tumors. Although granulosa cells normally occur only in the ovary, granulosa cell tumors occur in both ovaries and testicles. These tumors should be considered malignant and be treated in the same way that other malignant tumors of ovary are treated (2). Adult granulosa cell tumors occur in women 50 to 55 years of age but may occur at any age. Juvenile granulosa cell tumor is similar to adult type; however, it usually occurs in both the ovary and testis of children and adolescents. Granulosa cell tumor of testis is extremely rare and has not been reported to be malignant $(3,4)$. Ovarian tumors rarely occur in children, accounting for only $1 \%$ of all childhood malignancies. Granulosa cell tumor (GCT), after ovarian cyst, is the most common source of autonomous ovarian estrogen. Only 4-5 percent of GCTs occur in children (5). Although isosexual precocious puberty in girls is idiopathic in origin, but this is a diagnosis of exclusion, and many differential diagnoses have to be thought of in evaluation of precocity in girls (6). Estrogen-secreting tumors are rare etiology of precocious puberty; however, the most common presentation of these tumors in children is precocious puberty. Estrogen is produced by functioning tumors and the clinical presentations depend on the patient age and sex. GCT presentations in postmenopausal women may usually be accompanied by abnormal uterine bleeding; In the women of reproductive age, menometrorrhagia will be presented. If the patient has not undergone puberty yet, early onset of puberty may be seen. This case report was performed in order to assess the presentations of precocious puberty in a girl with juvenile granulosa cell tumor.

\section{Material \& Methods:}

A three years old girl was admitted to the Pediatric clinic in Children hospital, presented with breast enlargement but with no significant past medical history, pain and abdominal swelling.

\section{Results:}

Pelvic ultrasonography showed a hypoechoic solid mass and abdominopelvic MRI (magnetic resonance imaging) with and without contrast showed left adnexal enhancing mass with multiple cystic components, pushing adjacent loops to the right side with tumor adhesion to anterior bowel loops. Physical examination showed premature telarche in this patient (Figure1). Microscopic features of the resected mass were characteristic of juvenile GCT (Figure 2).

\section{Discussion:}

Adult granulosa cell tumor of the ovary is a stromal cell neoplasm able to secrete steroids such as estrogen. Vaginal bleeding caused by endometrial hyperplasia or uterine cancer may be accompanied by GCT. Some clinical symptoms of GCT include abdominal pain, hypotension, and hemoperitoneum after tumor rupture. Moreover, in the women of reproductive age, it may be diagnosed ectopic pregnancy (EP) by mistake because of similar presentations with EP. Physical examination may show pelvic mass. Surgery is performed in order to determine of definite histologic diagnosis, tumor staging, and debulking. Surgery management of this type of tumors is different based on age in females. Hence, surgical tumor removal includes total abdominal hysterectomy and bilateral salpingo-oophorectomy in older women and a more conservative unilateral salpingooophorectomy in the women of reproductive age, respectively $(7,8)$. Juvenile Granulosa cell tumors defined in 1976 by Scully is mostly found in girls during the first two decades of life. Characteristic histological features of these tumors include solid follicular formation and cysts, nodular architecture, irregular microcysts, cell necrosis, abundant interstitial and intrafollicular acid mucopolysaccharide-rich fluid, and high mitotic activity $(9,10)$. In this case report a three-year-old girl with premature telarche and precocious puberty 
was assessed. Microscopic and imaging results demonstrated the cause of this precocious puberty was juvenile granulosa cell tumor. Therefore, this study and other studies show precocious puberty in children is mostly the presentation of GCT (11). Among all granulosa cell tumor subtypes, Juvenile granulosa cell tumors occur rarely. Juvenile granulosa cell tumors are presented with clinical signs of hyperestrogenism precocious puberty in prepubertal patients, menstrual irregularities in women of reproductive age, and abnormal uterine bleeding in postmenopausal women. In children with GCT, surgery should be performed with unilateral oophorectomy for stage one. Adjuvant chemotherapy is not used for stage one (11). Prognosis depends on presentations of tumor stage after diagnosis. Diagnosis at stage $\mathrm{I}$ is with a favorable prognosis whereas diagnosis at stages II through IV is with higher rate of disease recurrence and poor prognosis. Granulosa cell tumors in premenarchal girls appear to have better prognosis than adult women (12).

\section{Conclusion:}

This case documents a rare cause of precocious puberty, a juvenile granulosa cell tumor of the ovary. Although Ovarian Estrogen-secreting tumors are rare etiology of precocious puberty, the most common presentation of GCT in children is precocious puberty. Therefore, precocious puberty must be considered as a probable presentation of these tumors.

\section{Conflict of interest statement:}

The author declared no conflict of interest.

\section{Acknowledgments:}

I have no acknowledgements to disclose.
Figure1: A three years old girl with precocious puberty (breast enlargement).

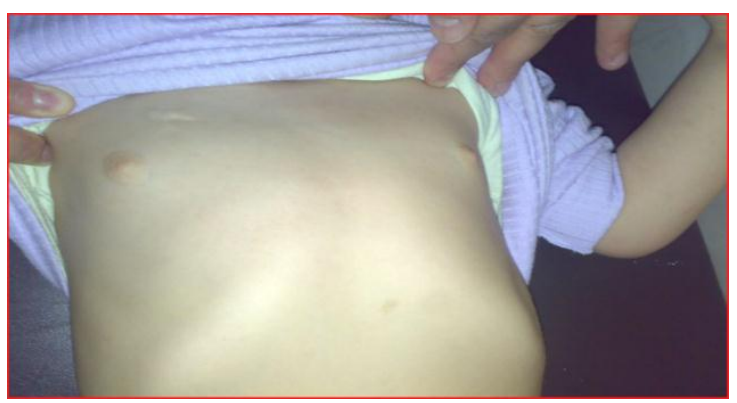

Figure2. Micrograph of a juvenile granulosa cell tumour with hyaline globules. H\&E stain.

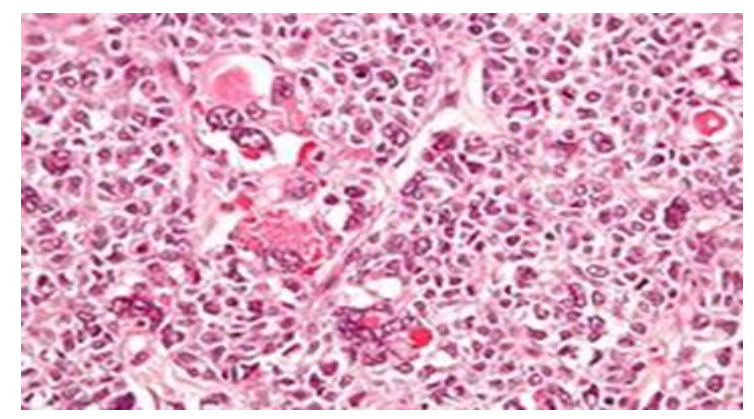




\section{References:}

1.Calamins G, Wessalowski R, Harms D, Gobel U. Juvenile granulosa cell tumors of the ovary in children and adolescents.Gynecol oncol. 1997; 65(3): 447-452

2. Genaecology.3rd Ed.2003 churchill livingstone. PP.690-691.

3.Dudani R, Giordano L, Sultania P, Jha K, Florens A, Josef T. Juvenile granulosa cell tumor of testis:case report and review of literature.AM J Perinatol. 2008; 25(4):229-231

4. Lin KH,Lin SE,Lee LM. Juvenile granulosa cell tumor of adult testis: a case report.Urology. 2008; 72(1): 230.e11-3.

5. Breen JL,Maxon WS.Ovarian tumours in children and adolescents.Clin Obstet Gynecol.1997;20(3):607-623

6. Nisha NH,Gaurav A,Rakesh P,Preeti D.Juvenile granulosa cell tumour presenting as isosexual precocious puberty:a case report and review of literature.Indian $\mathrm{J}$ Endocrinol Metab.2013;17(1):157-159

7. Pectasides D, Pectasides E, Psyrri A. Granulosa cell tumor of the ovary. Cancer Treat Rev. 2008; 34(1): 1-12.

8.Schumer ST, Cannistra SA. Granulosa cell tumor of the ovary. J Clin Oncol. 2003; 21: 11801189.

9. Zuntová A, Motlík K, Smelhaus V, Horejsí J. Juvenile granulosa cell tumor. Sborník lékařský. 1990; 92(4): 103.

10. Biscotti, C. V., \& Hart, W. R. Juvenile granulosa cell tumors of the ovary. Arch Pathol Lab Med. 1989; 113(1): 40-6.

11. Hashemipour M, Moaddab MH, Nazem M, Mahzouni P, Salek M . Granulosa cell tumor in a six-year-old girl presented as precocious puberty. J Res Med Sci. 2010; 15(4): 240-2.

12. Long JR, Danielson D. granulosa cell tumor of the ovary. Apllied Radiology. 2008; 37(11): 44-48. 